\title{
MORFEM DERIVASIONAL DALAM BAHASA MANDARIN
}

\author{
Yulie Neila Chandra
}

\begin{abstract}
Abstrak
Afiksasi merupakan satu di antara beberapa jenis proses morfologis di dalam Bahasa Mandarin. Afiks (imbuhan) adalah morfem terikat yang ditambahkan pada morfem lain untuk membentuk unit yang lebih besar, seperti kata, khususnya membentuk kata majemuk/gabungan (合成词 héchéng cî). Bahasa Mandarin memiliki dua macam afiks, yaitu prefiks (awalan) dan sufiks (akhiran). Di dalam Bahasa

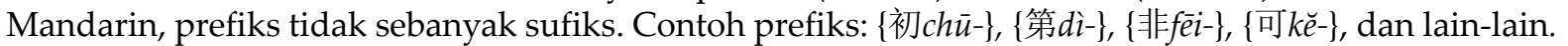

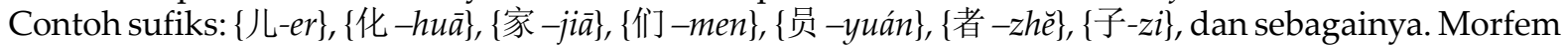
afiks dibagi menjadi dua kategori, yaitu morfem infleksional dan morfem derivasional. Kedua morfem tersebut merujuk pada dua macam proses pembentukan kata, yakni infleksi dan derivasi. Akan tetapi, dapat dikatakan bahwa Bahasa Mandarin bukanlah bahasa infleksi, sehingga yang termasuk morfem

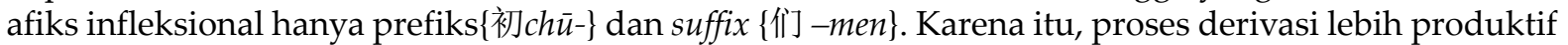
di dalam Bahasa Mandarin. Morfem derivasional membentuk kata baru yang dapat mengubah makna dasar atau akar, serta dapat mengubah kelas kata, seperti menjadi nomina, verba, dan adjektiva. Namun, pada umumnya membentuk nomina.
\end{abstract}

\section{Kata Kunci}

Afiksasi, morfem terikat, infleksional, derivasional.

\begin{abstract}
Affixation is one of the process of morphological in Mandarin. Affixes are bound morphemes that are added to other morphemes to form larger units such as words, especially to form a compound word (成词 héchéng cí). Mandarin has two types of affixes: prefixes (precedes the morpheme) and suffixes

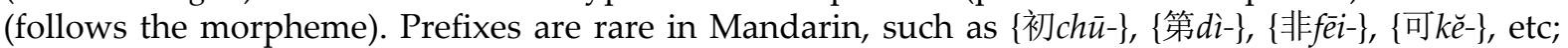
while suffixes are more numerous, such as $\{儿-e r\},\{$ 化 $-h u \bar{a}\},\{$ 家 $-j i \bar{a}\},\{$ 们 - men $\},\{$ 员 $-y u a ́ n\},\{$ 者 $-z h \breve{e}\},\{$ 子-zi\}, etc. In Mandarin, affix morphemes can also be divided into two functional categories, namely inflectional morphemes and derivational morphemes, both refers two principal word formation processes: inflection and derivation. Although, Mandarin is not the inflection language, only prefix

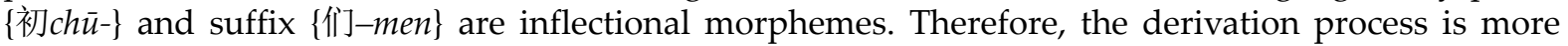
productive in Mandarin. Derivational morphemes form new words by changing the meaning of the base (root) and the word class. In consequence, derivation in Mandarin may cause a change of word classes; such as nouns, verbs, and adjective, but generally form nouns.
\end{abstract}

Keywords

Affixation, bound morphemes, inflectional, derivational .

\section{PENDAHULUAN}

Bahasa Mandarin merupakan salah satu bahasa yang unik di antara sekian banyak 
bahasa di dunia. Keunikan itu dapat dilihat dari sistem tulisannya yang berbentuk aksara atau huruf balok, yang disebut 方块字 fàngkuàizì. Huruf tersebut tidak berbentuk ortografi, melainkan menyerupai ideogram dan piktogram. Setiap aksara balok terdiri atas guratan-guratan yang mewakili satu sukukata atau silabel, bukan mewakili satu fonem. Karena itu, 汉字 Hànzi ‘aksara Han' dapat disebut sebagai 音节字 yīnjiézi ‘aksara silabis', yakni sistem tulisan yang menggunakan satu lambang untuk menggambarkan satu sukukata. Sukakata-sukukata tersebut pada umumnya memiliki makna, baik makna leksikal maupun gramatikal, sehingga aksara Han dapat juga dikatakan sebagai 词素字 císùzì atau 语素字 yŭsùzì 'aksara morfemis'. Dengan demikian, sebagian besar setiap aksara Han dapat mewakili sebuah morfem.

Dari salah satu keunikan Bahasa Mandarin itu, menimbulkan sifat keuniversalan bahasa, yang antara lain adalah konsep morfem dalam Bahasa Mandarin sama dengan bahasa lain di dunia. Morfem yang dalam istilah Bahasa Mandarin disebut 词素 císù atau 语素 yŭsù, ialah satuan gramatikal terkecil yang memiliki makna, secara relatif stabil dan tidak dapat dibagi atas bagian bermakna yang lebih kecil. Dikatakan bermakna karena tidak hanya menunjukkan sebuah makna yang mengandung pemahaman yang konkret, tetapi juga menunjukkan makna yang berfungsi secara gramatikal. Karenanya, morfem dapat memiliki makna leksikal ataupun gramatikal.

Morfem juga merupakan konstituen pembentuk satuan-satuan gramatikal yang lebih besar, khususnya kata. Misalnya, dalam Bahasa Indonesia morfem dasar yang bebas seperti $\{$ main\}, mendapat proses morfologis afiksasi dengan morfem afiks yang terikat seperti $\{$ ber-\}, sehingga menjadi sebuah kata bermain. Contoh lain lagi, dalam Bahasa Inggris kata books terdiri dari dua morfem, yaitu yang dasar dan bebas $\{b o o k\}$, dan yang afiks dan terikat $\{-s\}$. Hal tersebut juga terjadi di dalam Bahasa Mandarin, seperti 画 huà 'melukis; menggambar' ditambah dengan morfem afiks 儿\{-er\}, menjadi 画 儿 huàr 'lukisan; gambaran'.

Proses morfologis di dalam setiap bahasa sangat beragam, salah satunya adalah afiksasi, yakni proses penambahan afiks, yang disebut juga pengimbuhan. Afiks terdiri atas empat macam, yaitu prefiks (awalan), infiks (sisipan), sufiks (akhiran), dan konfiks atau sirkumfiks (apitan, yakni di awal dan akhir). Sementara itu, afiksasi sejatinya terbagi menjadi dua macam, yaitu infleksi dan derivasi. Infleksi ialah perubahan bentuk suatu kata untuk menunjukkan suatu hubungan gramatikal. Dengan kata lain, infleksi menunjukkan adanya penambahan unsur sehingga dapat membatasi tugas gramatikal kata yang dibentuknya. Contoh: sufiks $\{-s\}$ ditambahkan pada bentuk dasar verba work, menjadi works 'bekerja', menyatakan infleksi verba persona ketiga; sufiks $\{-s\}$ ditambahkan pada bentuk dasar book 'buku', menjadi books 'buku-buku', menyatakan infleksi plural/jamak. Sebaliknya, derivasi ialah perubahan suatu kata menjadi kata baru atau kata yang berbeda. Karena itu, derivasi tidak bersifat infleksi, melainkan dapat mengubah makna dan kelas kata. Contoh: sufiks \{-er\} ditambahkan pada bentuk 
dasar verba read 'baca' menjadi nomina reader 'pembaca'. Proses infleksi juga dapat berkelindan dengan kala. Misalnya dalam Bahasa Inggris, sufiks \{-ed\} yang melekat pada verba seperti walk, menjadi walked, menyatakan kala lampau. Namun sebaliknya, proses derivasi tidak memedulikan hal tersebut.

Katamba (1993) dalam bukunya yang berjudul Morphology, memaparkan bahwa morfem-morfem afiks dapat dibagi menjadi dua kategori fungsionalnya, yaitu morfem infleksional dan morfem derivasional. Keduanya merujuk pada dua proses morfologis, yakni infleksi dan derivasi. Karena itu, infleksional dan derivasional membentuk kata-kata dengan cara yang berbeda. Morfem derivasional dapat membentuk kata baru. Dengan kata lain, morfem tersebut dapat mengubah makna dasar, serta dapat mengubah kelas kata. Katamba juga memberikan berbagai contoh infleksi dan derivasi, serta menunjukkan morfem infleksional dan derivasionalnya dengan sangat jelas, seperti contoh berikut ini (Katamba, 1993: 48):

A

$\mathrm{B}$

$\begin{array}{llll}\text { I ducked } & \text { 'saya merunduk' } & \text { He was sheepish } & \text { 'ia malu-malu' } \\ \text { He ducks } & \text { 'ia merunduk' } & \text { He is humourless } & \text { 'ia tidak jenaka' } \\ \text { two ducks } & \text { 'dua ekor itik' } & \text { three ducklings } & \text { 'tiga ekor anak itik' }\end{array}$

Contoh di atas memperlihatkan dua kelompok. Kelompok pertama (A) terdapat tiga sufiks, yakni -ed, -s pemarkah kala kini persona ketiga, dan -s pemarkah jamak; sedangkan kelompok kedua (B) terdapat sufiks -ish, -less, -ling, dan -s pemarkah jamak. Contoh tersebut dapat digambarkan seperti berikut ini:

\begin{tabular}{llll}
\multicolumn{1}{r}{ Sufiks } & Masukan & Keluaran & \\
a) - ed & Verba & Verba & : duck à ducked \\
b) - S & Verba & Verba & : duck à ducks \\
c) - N & Nomina & Nomina & : duck à ducks \\
d) - ish & Nomina & Adjektiva & : sheep à sheepish \\
e) -less & Nomina & Adjektiva & : humour à humourless \\
f) -ling & Nomina & Nomina & : duck à duckling
\end{tabular}

Contoh (a), (b), dan (c) menunjukkan proses infleksi. Sufiks infleksional -ed sebagai pemarkah kala lampau; sufiks infleksional $-s$ pada contoh (b) sebagai pemarkah kala kini persona ketiga, sedangkan sufiks infleksional -s pada contoh (c) menyatakan bentuk jamak. Ketiga proses tersebut menghasilkan kelas kata yang sama dengan kelas kata dasarnya. Sebaliknya, contoh (d), (e), dan (f) menunjukkan proses derivasi. Sufiks -ish yang melekat pada nomina sheep menghasilkan kata baru dengan kelas kata yang 
berbeda. Begitu pula dengan contoh (e), yang juga menghasilkan kata baru dengan kelas kata yang berbeda, yakni adjektiva. Kemudian, pada contoh (f) kata yang dihasilkan berkelas sama, yakni nomina, tetapi dari segi makna berbeda. Karena itu, contoh (f) juga merupakan proses derivasi.

Berdasarkan paparan di atas, di dalam makalah yang sederhana ini, saya berusaha menjelaskan bagaimana afiksasi dalam Bahasa Mandarin, khususnya derivasi yang dapat mengubah makna dan/atau kelas kata. Mengingat dalam Bahasa Mandarin tidak mengenal kala pada verbanya, maka tulisan ini menitikberatkan pada derivasi dalam Bahasa Mandarin sehingga dapat memahami berbagai macam morfem derivasionalnya.

\section{MORFEM BAHASA MANDARIN}

Klasifikasi morfem Bahasa Mandarin sering diwarnai oleh ketumpangtindihan, seperti pendistribusian morfem bebas dan morfem terikat yang kadang-kadang tidak jelas. Terlebih lagi, dalam Bahasa Mandarin terdapat morfem setengah bebas, yang kadang sulit membedakannya dengan morfem lainnya.

Menurut Fang Yuqing (1992/1996:45-50), morfem Bahasa Mandarin dapat dibagi menjadi tiga kelompok, yaitu

1) Berdasarkan kesanggupan gerak dari morfem atau berdasarkan bentuk, dibedakan atas tiga macam, yakni 自由语素 zìyóu yŭsù 'morfem bebas', 粘着语素 niánzhe yŭsù 'morfem terikat', 半自由语素 bàn zìyóu yŭsù 'morfem setengah bebas'.

2) Berdasarkan makna, terdiri dari 实语素 shíyŭsù (实词素 shícísù) 'morfem leksikal' dan 虚语素 $x \bar{u} y \breve{u}$ s̀̀ (虚词素 $x \bar{u} c i ́ s \grave{u}$ ) 'morfem gramatikal.

3) Berdasarkan silabel atau jumlah sukukata, terdiri dari 单音节语素 dānyīnjié yŭsù 'morfem monosilabis' dan 多音节语素 duōyiñjié yŭsù 'morfem polisilabis'.

Morfem bebas adalah morfem yang secara potensial dapat berdiri sendiri dalam suatu kalimat. Dalam Bahasa Mandarin, morfem ini sekaligus merupakan 单纯词 dānchúncí 'kata tunggal murni' dan juga 词根 cígēn 'roots' atau 'akar' dan 'dasar'. Contoh: \{人rén\} 'orang', \{我wŏ\} 'saya', \{爱ài $\}$ 'cinta', \{走zŏu\} 'jalan', \{树shù\} 'pohon', dan lain-lain. Morfem ini dapat bergabung dengan morfem lain membentuk kata, seperti 人民 rénmín 'rakyat', 工人 gōngrén 'buruh', 我们 wŏmen 'kami', 爱情 àiqing 'cinta', 喜爱xǐ' 'ài 'suka', 树 木 shùmù 'pohon', 树干 shùgān 'batang pohon', dan lain-lain.

Morfem terikat ialah morfem yang tidak berpotensi untuk berdiri sendiri, dan harus bergabung bersama morfem lain (yang umumnya berupa akar atau dasar) untuk membentuk suatu kata. Morfem terikat ini dapat berwujud morfem afiks atau bukan. Contoh: $\{$ 师 shī $\}$ merupakan morfem afiks (sufiks) bergabung bersama morfem

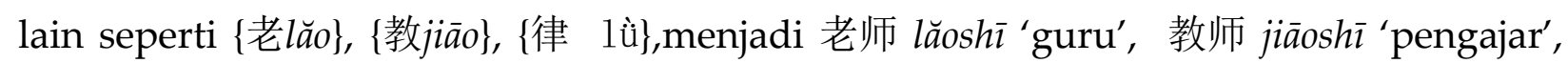
律师 lùsshi 'pengacara'; \{习x $\left.x_{i}\right\}$ bukan morfem afiks, harus bergabung dengan morfem lain sehingga menjadi 学习xuéxí ‘belajar', 练习liànxí 'latihan'; \{体tî\} bukan morfem afiks, 
bergabung dengan morfem lain menjadi 体力tǐlì 'kekuatan fisik', 体育tǐyù olahraga', dan lain-lain.

Morfem setengah bebas ialah morfem yang dalam penggunaan secara umum

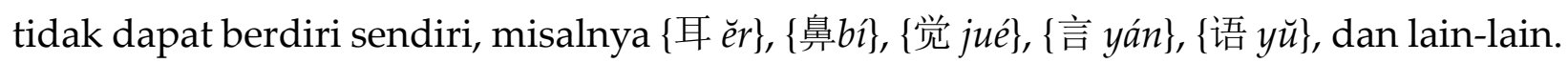

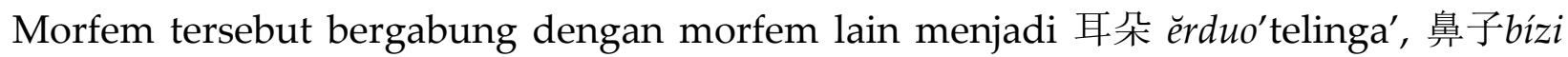
'hidung', 觉得juéde 'merasa', 语言 yŭyán 'bahasa'. Namun, dalam persyaratan tertentu dapat berdiri sendiri, yakni untuk ragam bahasa tertentu, misalnya ragam bahasa ilmu kedokteran, biologi, kimia, ragam bahasa jurnalistik, dan lain-lain. Selain itu, digunakan untuk 熟语 shúyŭ 'ungkapan' atau 成语 chéngyŭ 'idiom'. Contoh: \{耳 ěr $\}$ dan \{鼻bí\} dalam ragam bahasa ilmu kedokteran dapat berdiri sendiri; $\{$ 觉 jué\}, \{言 yán\}, dan \{语 yŭ $\}$ dalam bentuk idiom atau ungkapan dapat berdiri sendiri, seperti 不知不觉 bù zhì bù jué 'tanpa terasa', 自言自语 zì yán zì yŭ 'berbicara seorang diri'.

Morfem leksikal adalah morfem yang mengandung makna leksis, yakni menunjukkan makna yang konkret (jelas). Jumlah morfem ini tidak terbatas dan sangat produktif. Morfem leksikal mencakup 实词 shící 'full words/kata penuh' dalam Bahasa Mandarin, seperti 名词 míngcí 'nomina', 代词 dàicí 'pronomina', 动词 dòngcí 'verba', 形容 词 xíngróngcí 'adjektiva', 数词 shŭcí 'numeralia'.

Morfem gramatikal ialah morfem yang mengandung makna gramatis (berfungsi dalam pembentukan kalimat). Morfem ini jumlahnya terbatas dan umumnya berfungsi sebagai penghubung di antara morfem leksikal. Dalam Bahasa Mandarin, morfem gramatikal mencakup kata tugas. Selain itu, juga mencakup morfem afiks (yang umumnya adalah sufiks). Contoh: \{们 men\}, $\{$ 吗 $m a\},\{$ 的 $d e\},\{了 l e\},\{$ 子 $z i\}$, $\{$ 就 jiù $\}$, \{而 ér\}, dan sebagainya.

Morfem monosilabis adalah morfem yang jumlah silabelnya hanya satu. Sebagian besar morfem Bahasa Mandarin berbentuk monosilabis. Morfem ini dapat menjadi kata tunggal murni. Contoh: 他 tā 'ia', 好 hăo 'baik', 吃 chī 'makan', dan lain-lain.

Morfem polisilabis ialah morfem yang jumlah silabelnya lebih dari satu. Dalam Bahasa Mandarin, morfem ini tidak banyak. Contoh: \{葡萄 pútáo\} 'anggur', \{蚂蚁 măy 'semut', \{蜘蛛 $z h \bar{\imath} z h \bar{u}\}$ 'laba-laba', dan lain-lain. Morfem ini juga mencakup kata serapan terjemahan bunyi bahasa asing, misalnya 尼龙 nílóng 'nylon', 沙发 shāfā 'sofa', 马达 mădá 'motor', dan sebagainya. Morfem ini sekaligus merupakan kata monomorfem polisilabis.

Dari penjelasan di atas, jelas terlihat bahwa morfem Bahasa Mandarin sebagian besar merupakan morfem monosilabis dan sebagian kecil adalah morfem polisilabis, sehingga melalui berbagai proses morfologis akan menghasilkan berbagai bentuk kata, seperti 单词 dān cí 'kata tunggal' dan 合成词 héchéng cí 'kata gabungan/majemuk'. Misalnya, 我 wŏ 'saya' merupakan kata tunggal yang terdiri dari satu morfem (kata tunggal monomorfem monosilabis); 葡萄 pútáo 'anggur' merupakan kata tunggal polisilabis (bisilabis) yang terdiri dari satu morfem (kata tunggal monomorfem polisilabis); 巧克力 qiăokèlì 'cokelat' merupakan kata tunggal polisilabis yang terdiri dari 
satu morfem (kata tunggal monomorfem polisilabis); 学习 xuéxí ‘belajar' merupakan kata gabungan/majemuk polisilabis (bisilabis) yang terdiri dari dua morfem (kata polimorfem polisilabis); dan sebagainya.

\section{AFIKS BAHASA MANDARIN}

Seperti halnya dengan bahasa lain di dunia, morfem dalam Bahasa Mandarin juga dapat berwujud 词根 cígēn 'akar' atau 词干 cígàn 'pangkal', dan 词缀 cízhui 'afiks'. Namun, afiks Bahasa Mandarin hanya mencakup 前缀 qiánzhuì atau 词头 cítóu 'prefiks', dan 后缀 hòuzhuì atau 词尾 cíwěi ‘sufiks'. Afiks Bahasa Mandarin umumnya merupakan morfem terikat.

Zhao Yuanren dalam karya legendarisnya yang berjudul A Grammar Spoken Chinese (1968), mengungkapkan bahwa pada dasarnya afiks dalam Bahasa Mandarin merupakan afiks yang dipaksakan dengan menggunakan teori barat. Hal tersebut disebabkan huruf Han berdiri sendiri-sendiri dan berbentuk sukukata. Karena itu, menurutnya, prefiks dikelompokkan menjadi dua macam, yakni yang merupakan terjemahan bahasa asing, seperti \{单 dān-\} 'uni-, mono-' dalam kata dānfāngmiàn 'unilateral, dānyīnjié 'monosilabis'; dan yang bukan terjemahan bahasa asing, seperti \{第dì-\} 'ke-' dalam kata 第一 dìy 'pertama', 第二dìèr 'kedua', dan sebagainya. Jumlah prefiks dalam Bahasa Mandarin sangat sedikit. Sebaliknya, sufiks dalam Bahasa Mandarin cukup banyak. Umumnya, morfem sufiks Bahasa Mandarin merupakan morfem gramatikal bertona netral, seperti $\{$ 子 $-z i\},\{儿-e r\}$, dan $\{$ 们 $-m e n\}$. Akan tetapi, Zhao Yuanren juga mengemukakan bahwa sufiks Bahasa Mandarin sangat beragam, seperti sufiks pembentuk kata majemuk, sufiks modern, sufiks nomina, sufiks verbal, sufiks subordinatif, dan lain-lain.

Zhao Yuanren juga mengungkapkan berbagai macam sufiks berdasarkan maknanya. Misalnya, sufiks yang menyatakan orang/pelaku/ahli, yakni $\{$ 者 $-z h \breve{e}\},\{$ 师 -sh $\bar{\imath}\}$, $\{$ 家-jiā \}, \{员-yuán\}, \{士-shì\}, \{人-rén\}, dan lain-lain; sufiks yang menunjukkan sifat; pikiran; atau perasaan, yakni $\{$ 性-xìng\}, $\{$ 心 -xīn\}, dan lain-lain; sufiks yang menyatakan cara; ilmu;

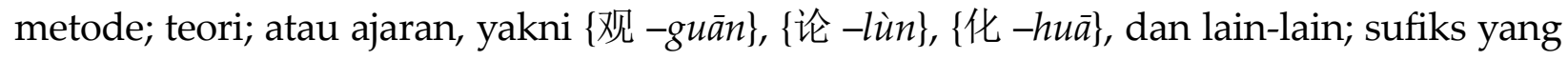
menunjukkan konjungsi, yakni\{然 -rán\}, dan lain-lain; sufiks yang menunjukkan benda atau tempat, yakni $\{儿-e r\},\{\}-z i\},\{$ 头-tóu\}, dan lalin-lain; sufiks yang menyatakan jamak, yakni $\{$ 们 $-m e n\}$; dan yang terakhir adalah sufiks bantu/modal, yakni $\{$ 么 $-m e\}$.

Pandangan yang berbeda dikemukakan oleh Fang Yuqing (1992/1996:54-56). Ia tidak mengelompokkan jenis-jenis prefiks dan sufiks. Fang Yuqing mengungkapkan bahwa prefiks Bahasa Mandarin yang sebenarnya sangat sedikit, yakni $\{$ 第dì-\}, $\{$ 老lăo-\},

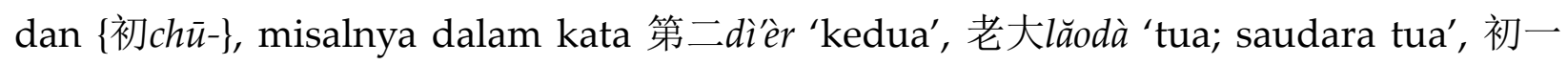
chū $y \bar{\imath}$ 'pertama'. Sementara itu, prefiks lainnya seperti $\{$ 可 $k \breve{e}-\}$, \{反făn-\}, \{非fē $\dot{i}-\}$, dan lainlain, merupakan perkembangan menjadi prefiks. Menurut Fang Yuqing (1992/1996), yang dapat digolongkan ke dalam sufiks Bahasa Mandarin adalah $\{$ 者 $-z h \breve{e}\},\{$ 然 -rán\}, \{

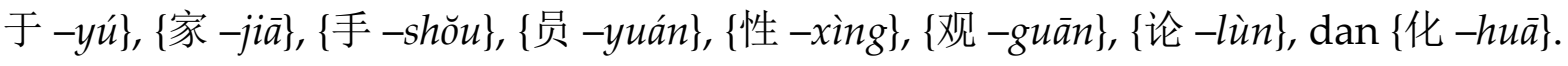


Sejalan dengan Fang Yuqing, Sun Dejin (2002: 27-28) juga mengungkapkan morfemmorfem afiks tersebut. Namun, ia membagi sufiks menjadi tiga bagian, yaitu (1) sufiks pembentuk nomina: $\{$ 者 $-z h \breve{e}\},\{$ 性 $-x i n g\},\{$ 家 $-j i \bar{a}\},\{$ 员 $-y u a ́ n\},\{$ 观 $-g u \bar{u} n\}$, dan $\{$ 手-shŏu\}; (2) sufiks pembentuk adjektiva: $\{$ 式 -shi\}, \{型 -xing\}, keduanya memiliki makna yang serupa, yakni 'tipe; model; atau pola'; dan (3) sufiks pembentuk verba: $\{$ 化 $-h u \bar{a}\},\{$ 于-yú\}.

Sebaliknya, Lü Shuxiang dan kawan-kawan (2010) dalam bukunya yang berjudul 现代汉语八百 Xiàndài Hànyŭ Bā Băi Cí, mengungkapkan beberapa macam afiks yang dapat dikatakan afiks sesungguhnya. Karena itu, karya mereka dipandang lebih komprehensif dari segi pemaparan setiap prefiks maupun sufiks. Menurut mereka, yang

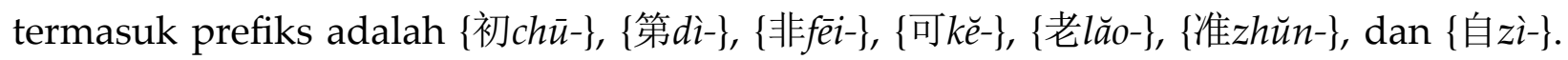
Kemudian, yang termasuk sufiks adalah $\{$ 儿-er $\},\{$ 化 $-h u \bar{a}\},\{$ 家 $-j i \bar{a}\},\{$ 们 $-m e n\},\{$ 手 -shŏu\}, \{ 头tóu\}, \{性 $-x i n g\},\{$ 员 $-y u a ́ n\},\{$ 者 $-z h e \breve{e}\}$, dan $\{$ 子-zi\}.

\section{AFIKSASI DALAM BAHASA MANDARIN}

Afiksasi dalam Bahasa Mandarin termasuk salah satu dalam proses pembentukan héchéng cí. Ada berbagai istilah afiksasi atau pengimbuhan dalam Bahasa Mandarin, yakni 附加法 fùjiāfă, 加词缀 jiā cízhuì, 附加作用 fùjiā zuòyòng, 词附法 cífüfă, atau 附加式 合成词 fùjiā shì héchéng cí. Pada prinsipnya konsep tersebut sama, yakni penambahan atau pengimbuhan pada suatu dasar atau akar. Oleh karena itu, pola afiksasi ada dua macam, yaitu

(1) 前缀 qiánzhuì atau 词头 cítóu 'prefiks' + 词根 cígēn 'akar'(dasar), contoh:

- 第dì + 三sān 'tiga' à 第三 dìsān 'ketiga'

- 非 fēi + 正式 zhèngshì 'formal' à 非正式 fēizhèngshì 'informal'

（2）词根 cígèn 'akar'(dasar)+后缀 hòuzhuì atau 词尾 cíwèi 'sufiks', contoh:

- 刷 shuā 'sikat; menyikat' + 子 $z i$ à 刷子 shuāzi 'sikat; penyikat'

- 演 yăn 'mementaskan; mempertunjukkan' + 员 yuán à 演员 yănyuán 'pemain; penampil'

- 记 jì 'mengingat, mencatat' + 者 zhĕ à 记者 jìzhĕ 'wartawan; reporter'

Seperti bahasa lain di dunia, proses pengimbuhan dalam Bahasa Mandarin dapat terjadi dalam dua cara, yakni 词形变化 cíxíng biànhuà 'infleksi' dan 派生法 pàishēngfă 'derivasi'. Kedua proses tersebut berkaitan dengan morfem afiksnya, baik morfem infleksional maupun derivasional.

\section{MORFEM DERIVASIONAL DALAM BAHASA MANDARIN}

Morfem infleksional dalam Bahasa Mandarin boleh dikatakan sangat sedikit. Hal itu disebabkan, Bahasa Mandarin bukanlah bahasa infleksi seperti bahasa-bahasa di 
Eropa pada umumnya. Karenanya, Bahasa Mandarin juga bukan bahasa yang mengenal kala. Dengan demikian, infleksi yang secara umum lebih merujuk kepada infleksi pemarkah kala, tidak ditemukan di dalam Bahasa Mandarin. Satu-satunya morfem infleksional Bahasa Mandarin yang paling sering dijumpai adalah $\{$ 们 - men\}, yakni sufiks infleksi pemarkah jamak, seperti pada kata 我们 wŏmen 'kami', 你们 nĭmen 'kalian', 他们 tāmen 'mereka', 朋友们 péngyoumen 'teman-teman', dan lain-lain. Selain sufiks \{-men\} tersebut, prefiks \{ 初 $c h \bar{u}$-\} juga merupakan morfem infleksional karena terdapat batasan secara struktural, yakni untuk menunjukkan urutan yang merujuk pada bilangan dari

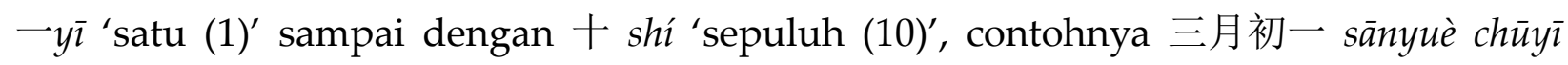
'tanggal 1 Pebruari'.

Sebaliknya, kebanyakan morfem afiks Bahasa Mandarin, baik morfem prefiks maupun sufiks, merupakan morfem derivasional, yang umumnya dapat mengubah makna dasar, dan juga kelas kata. Meskipun demikian, proses derivasi dalam Bahasa Mandarin tidak selalu mengubah kelas kata. Morfem derivasional Bahasa Mandarin tersebut sebagian besar dapat berfungsi sebagai pembentuk nomina; sedangkan sebagian kecil dapat menjadi pembentuk verba, atau adjektiva.

Prefiks $\{$ 非 $f \bar{e} i-\},\{$ 老lăo-\}, 准zhŭn-\} merupakan prefiks pembentuk nomina. Contoh:

1) 非 $f e \bar{i}+$ + 法fă 'hukum; legal' (nomina) à 非法fēifă 'ilegal' (nomina).

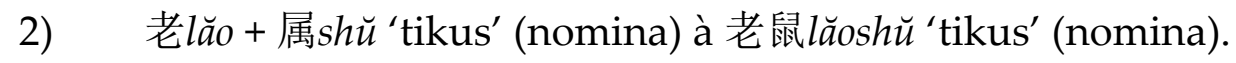

3) 准zhŭn + 尉 wèi 'pembantu letnan dua' (nomina) à 准尉 zhŭnwèi 'bintara perwira rendahan' (nomina).

Ketiga prefiks di atas membentuk kata berkelas nomina. Pada umumnya yang menjadi akar atau dasar juga nomina. Makna prefiks \{非 -fēi $\}$ menunjukkan sesuatu tidak termasuk dalam ruang lingkup tertentu. Makna prefiks \{老 -lăo\} tidak menyatakan usia tua, sedangkan prefiks $\{$ 准 $-z h \breve{u} n\}$ menyatakan sesuatu yang kurang, tetapi tetap dapat dihargai. Kemudian, Prefiks $\{$ 非 $-f e ̄ i\}$ ini juga dapat diikuti oleh verba, misalnya:

1) 非 fēi + 卖品mài p̌̆n 'menjual barang' (frase verba objek) à 非卖品 fēimàipŭn 'barang yang tidak untuk dijual' (nomina)

Prefiks $\{$ 可 $k \breve{e}-\}$ merupakan prefiks pembentuk adjektiva. Maknanya menunjukkan keadaan perasaan hati; boleh; harus; sesuai; cocok. Prefiks ini dapat diikuti verba atau nomina. Kata yang dihasilkannya adalah adjektiva. Contoh:

1) 可 $k \breve{e}+$ 爱ài 'cinta; suka' (verba) à 可爱kě'ài 'manis; lucu; tercinta' (adjektiva)

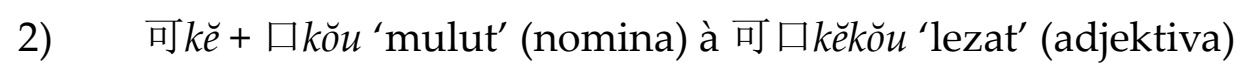

Prefiks $\{$ 自 -zi\} merupakan prefiks pembentuk verba, yang maknanya mengacu kepada diri sendiri. Contoh:

1) 自zì + 问wèn 'bertanya' (verba) à 自问zìwèn 'bertanya kepada diri sendiri' (verba) 
Sufiks derivasional pembentuk nomina, yakni $\{儿-e ́ r\}(e r),\{$ 家 $-j i \bar{a}\},\{$ 手 - shŏu $\},\{$ 头-tóu $\}$ (tou), \{性 $-x i n g\},\{$ 员 $-y u a ́ n\},\{$ 者 $-z h \breve{e}\}$, dan $\{$ 子 $-z i\}$. Contoh:

1) 罩zhào 'menutup' (verba) + 儿er à 罩儿zhàor 'penutup; masker' (nomina)

2) 空kōng 'kosong' (adjektiva) + 儿er à 空儿 kōngr 'tempat/waktu kosong' (nomina)

3) 个gè 'penggolong benda/orang' (kata penggolong) + 儿er à 个儿gèr 'ukuran tubuh/ benda' (nomina)

Sufiks $\{$ 儿 - er $\}$ pada contoh di atas, selain dapat melekat di belakang nomina, juga dapat melekat pada verba, adjektiva, serta kata penggolong. Namun, kata yang dihasilkannya adalah nomina. Makna sufiks ini dapat menyatakan sesuatu yang kecil; kesenangan; kedekatan.

1) 政治zhèngzhì 'politik' (nomina) + 家jiā à 政治家zhèngzhìjiā 'politikus' (nomina)

2) 画huà 'melukis;menggambar' (verba) + 家jiā à 画家huàjiā 'pelukis' (nomina)

Sufiks $\{$ 家 -jiā $\}$ pada contoh di atas dapat melekat pada nomina dan verba. Makna sufiks tersebut menunjukkan seseorang yang memiliki keahlian dalam bidang tertentu; profesi; pengikut ajaran tertentu; atau kelompok tertentu. Kata yang dihasilkannya adalah nomina.

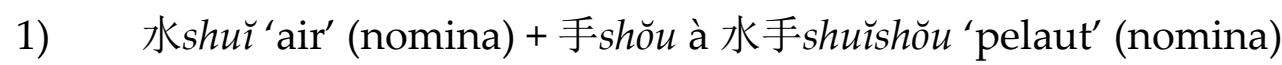

2) 好hăo 'baik; bagus' (adjektiva) + 手 shŏu à 好手hăoshŏu 'ahli; profesional' (nomina)

3) 选xuăn 'memilih' (verba) + 手shŏu à 选手xuănshŏu 'atlet yang terpilih (nomina)

Sufiks \{手-shŏu\} pada contoh di atas dapat melekat pada nomina, adjektiva, dan juga verba. Makna sufiks ini hampir sama dengan sufiks $\{$ 家 -jīa $\}$, yakni menyatakan orang yang ahli di bidang tertentu. Kata yang dihasilkannya juga menunjukkan nomina.

1) 馒mán 'roti; roti sepan' (nomina) + 头tou à 馒头mántou 'roti sepan' (nomina)

2) 念niàn 'belajar; memikirkan' (verba) + 头 tóu à念头niàntou 'pikiran; gagasan' (nomina)

Sufiks $\{$ 头 - tou $\}$ seperti contoh di atas, dapat mengikuti nomina dan verba. Kata yang dihasilkannya adalah nomina. Sufiks ini bila mengikuti verba atau adjektiva dapat menghasilkan nomina abstrak seperti contoh (16).

1) 时间shíjiān 'waktu' (nomina) + 性xìng à 时间性shíjiānxìng 'ketepatan waktu; batasan waktu' (nomina)

2) 弹tán 'menembak' (verba) + 性xìng à 弹性tánxìng 'elastisitas' (nomina)

Sufiks $\{$ 性 $-x i n g\}$ pada contoh di atas dapat mengikuti nomina dan verba. Kata yang dihasilkannya menunjukkan nomina, yang umumnya adalah nomina abstrak.

1) 店diàn 'toko' (nomina) + 员yuán à 店员 diànyuán 'pramuniaga' (nomina)

2) 服务fúwù̀ 'melayani'(verba) + 员 yuán à 服务员fúwù̀yuán 'pelayan' (nomina) 
Sufiks \{员 $-y u a ́ n\}$ pada contoh di atas juga dapat mengikuti nomina dan verba. Makna sufiks ini hampir sama dengan sufiks $\{$ 家 $-j i \bar{a}\}$, yakni menyatakan orang yang ahli atau memiliki profesi tertentu. Kata yang dihasilkannya pun adalah nomina.

1) 译yì 'menerjemahkan' (verba) + 者zhĕ à 译者 yìzhĕ 'penerjemah' (nomina)

2) 作zuò 'mengerjakan; membuat' (verba) + 者zhĕ à 作者zuòzhĕ 'pengarang; penulis' (nomina)

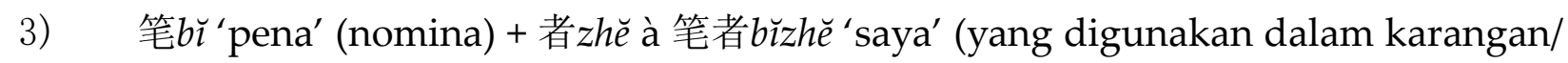
tulisan) (nomina)

4) 弱ruò 'lemah' (adjektiva) + 者zhĕ à 弱者ruòzhĕ 'orang lemah/tidak berpengaruh/ tidak normal' (nomina)

Sufiks $\{$ 者 $-z h \breve{e}\}$ pada contoh di atas, dapat melekat pada verba, nomina, dan adjektiva. Makna sufiks ini juga mengacu kepada pelaku, atau orang yang bekerja di bidang tertentu. Karena itu, maknanya hampir sama dengan sufiks $\{$ 家 $-j i \bar{a}\}$ atau $\{$ 员 yuán\}. Kata yang dihasilkannya juga menunjukkan nomina.

1) 帽mào 'topi (nomina) + 子 zi à 帽子 màozi 'topi' (nomina)

2) 个gè ‘penggolong benda/orang' (kata penggolong) + 子 $z i$ à 个子gèzi 'postur; ukuran tubuh' (nomina)

3) 胖pàng 'gemuk' (adjektiva) + 子zi à 胖子 pàngzi 'orang gemuk' (nomina)

4) 剪jiăn 'menggunting' (verba) + 子 $z i$ à 剪子jiănzi 'gunting' (nomina)

Sufiks $\{$ 子 $-z i\}$ seperti empat contoh di atas, dapat melekat pada berbagai kelas kata, yakni nomina, kata penggolong nomina, adjektiva, dan verba. Namun, kata yang dihasilkannya adalah nomina.

Sufiks derivasional pembentuk verba, yaitu $\{$ 化 -huà $\}$. Contoh:

1) 美mĕi 'cantik' (adjektiva) + 化huà à 美化mĕihuà 'memperindah; mempercantik' (verba)

2) 现代xiàndài 'modern' (nomina) + 化huà à 现代化xiàndàihuà 'modernisasi' (verba)

3) 退tuì 'mundur' (verba) + 化huà à 退化tuìhuà 'degenerasi; memburuk' (verba)

Sufiks \{化-huà\} dapat dikatakan satu-satunya sufiks pembentuk verba. Sufiks ini dapat melekat di belakang nomina, adjektiva, dan verba. Makna sufiks ini menunjukkan suatu perubahan kondisi, keadaan, kualitas, atau sifat. Kata yang dihasilkannya pun menunjukkan verba, baik transitif maupun intransitif.

Selanjutnya, sufiks derivasional yang dapat menjadi pembentuk adjektiva adalah $\{$ 性 -xing\}, yang pada umumnya melekat pada adjektiva, serta di belakang sufiks tersebut ditambah partikel struktural 的 de. Contoh:

1) 硬ying 'keras' (adjektiva) + 性xìng à 硬性yìngxìng 'keras; kaku' (adjektiva)

2) 流行liúxing 'populer' (adjektiva)+ 性xìng à 流行性liúxíngxing 'epidemis' (adjektiva) 
3) 综合zōnghé 'mengumpulkan; menyusun; menyintesis' (verba) + 性xìng à 综合性 zōnghéxing 'sintetik; sintesis' (adjektiva)

\section{PENUTUP}

Afiksasi juga dijumpai di dalam Bahasa Mandarin. Afiks Bahasa Mandarin yang hanya meliputi prefiks dan sufiks, dapat melekat pada kata yang berkelas nomina, verba, adjektiva, dan kata penggolong. Proses tersebut sebagian besar menghasilkan nomina, sedangkan sebagian kecil menghasilkan verba dan adjektiva. Bahasa Mandarin bukan bahasa infleksi sehingga derivasilah yang mendominasi afiksasi. Karena itu, morfem afiks Bahasa Mandarin pada umumnya merupakan morfem derivasional. Kehadiran morfem tersebut dapat mengakibatkan perubahan pada kata yang dihasilkannya, baik makna maupun kelas katanya. Namun demikian, derivasi dalam Bahasa Mandarin tidak selalu mengubah kelas kata.

\section{PUSTAKA ACUAN}

Bauer, Laurie. Introducing Linguistic Morphology. London: Edinburgh University Press. 1988.

Fang Yuqing. 实用汉语语法 Shiyong Hanyu Yufa (Gramatika Bahasa Mandarin Praktis). Beijing: Beijing Yuyan Xueyuan Chubanshe. 1992.

Kridalaksana, Harimurti. Kelas Kata dalam Bahasa Indonesia. Jakarta: Gramedia. 1990. Introduction to Word Formation and Word Classes in Indonesian. Depok:

Fakultas Sastra Universitas Indonesia. 1998. . Tata Wacana Deskriptif Bahasa Indonesia. Jakarta: FSUI. 1999.

Katamba, Francis. Morphology. London: Macmillan Press Ltd. 1993.

Li, Charles N. dan Sandra A. Thompson. Mandarin Chinese: A Functional Reference Grammar. Berkeley: University of California Press. 1981.

Luo Xiaosuo. 现 代 汉 语 引 论 Xiandai Hanyu Yinlun (Introduction to Modern Chinese). Yunnan: Yunnan Renmin Chubanshe. 1999.

Lü Shuxiang. 现代汉语八百词 Xiandai Hanyu Ba Bai Ci. Beijing: Shangwu Yinshuguan. 2010.

Nida, Eugene A. Morphology: the Descriptive Analysis of Words ( $2^{\text {nd }}$ ed.). New York: The University of Michigan Press. 1949.

Sun Dejin. 汉语语法教程 Hanyu Yufa Jiaocheng. Beijing: Beijing Yuyan Daxue Chubanshe. 2003.

Zhang Wu. 简 明 现 代汉 语 Jianming Xiandai Hanyu. Beijing: Zhongyang Guangbo Dianshi Daxue. 2000.

Zhao Yuanren. A Grammar of Spoken Chinese. Berkeley: University of California Press. 1968. 